\title{
The Policy Process
}


This page intentionally left blank 


\section{The Policy Process \\ A Practical Guide for Natural \\ Resource Professionals}

Susan G. Clark

Yale University Press

New Haven and London 
This impression published in 2011. First published in 2002 under the name Tim W. Clark.

Published with assistance from the foundation established in memory of Philip Hamilton McMillan of the Class of 1894, Yale College.

Copyright $(2002$ by Yale University.

All rights reserved.

This book may not be reproduced, in whole or in part, including illustrations, in any form (beyond that copying permitted by Sections 107 and 108 of the U.S. Copyright Law and except by reviewers for the public press), without written permission from the publishers.

Set in Aster Roman type by Achorn Graphic Services, Worcester, Massachusetts.

Printed in the United States of America.

Library of Congress has cataloged the first printing as follows:

Clark, Tim W.

The policy process : a practical guide for natural resource professionals / Tim W. Clark.

p. $\mathrm{cm}$.

Includes bibliographical references and index.

ISBN: $978-0-300-09012-3$ (pbk.)

1. Conservation of natural resources-Decision making. I. Title.

\section{S944.5.D42 C63 2002}

333.7 '2-dc21

A catalogue record for this book is available from the British Library.

The paper in this book meets the guidelines for permanence and durability of the Committee on Production Guidelines for Book Longevity of the Council on Library Resources. 
The significant problems we face cannot be solved at the same level of thinking we were at when we created them.

Albert Einstein

The way we see the problem is the problem.... We need to understand our own "paradigms" and how to make a "paradigm shift.". . We need a new level, a deeper level of thinking-a paradigm based on the principles that accurately describe the territory of effective human being and interacting-to solve these deep concerns.

Stephen R. Covey

We think in generalities, we live in detail.

Alfred North Whitehead

If you are thinking a year ahead, sow seeds. If you are thinking ten years ahead, plant a tree. If you are thinking a hundred years ahead, educate people.

Kuan-Tsu, $\mathbf{3 d}$ century B.C. 
This page intentionally left blank 